\title{
Scale-specific density dependence in North Sea sandeel
}

\author{
Rindorf, Anna; Henriksen, Ole; van Deurs, Mikael
}

Published in:

Marine Ecology - Progress Series

Link to article, DOI:

$10.3354 /$ meps 12945

Publication date:

2019

Document Version

Peer reviewed version

Link back to DTU Orbit

Citation (APA):

Rindorf, A., Henriksen, O., \& van Deurs, M. (2019). Scale-specific density dependence in North Sea sandeel. Marine Ecology - Progress Series, 619, 97-110. https://doi.org/10.3354/meps12945

\section{General rights}

Copyright and moral rights for the publications made accessible in the public portal are retained by the authors and/or other copyright owners and it is a condition of accessing publications that users recognise and abide by the legal requirements associated with these rights.

- Users may download and print one copy of any publication from the public portal for the purpose of private study or research.

- You may not further distribute the material or use it for any profit-making activity or commercial gain

- You may freely distribute the URL identifying the publication in the public portal

If you believe that this document breaches copyright please contact us providing details, and we will remove access to the work immediately and investigate your claim 


\section{Scale-specific density dependence in North Sea sandeel}

2 By Anna Rindorf ${ }^{1}$, Ole Henriksen and Mikael van Deurs

3 Technical University of Denmark, National Institute of Aquatic Resources, Kemitorvet 1, 2800

$4 \quad$ Lyngby, Denmark.

$5 \quad{ }^{1}$ Email: ar@aqua.dtu.dk

7 Running page head

8 Local and regional density dependence

\section{Abstract}

11 Density dependent demographic processes occur in many marine fishes and potentially enhance the stability of local aggregations and regional populations. The degree of density dependence exhibited at the population level is a combination of local density dependent effects acting on different spatial scales. In this study, we searched for density dependence in recruitment, growth, and mortality of North Sea sandeel Ammodytes marinus at different spatial scales by analysing data at a spatial resolution specifically reflecting the mosaic of populated habitat patches. Two types of density dependent processes occurred: A shift in the spatial distribution towards low mortality areas when overall recruitment level was high and an increase in local mortality as local density increased. When combined, these processes largely compensated for each other and the size of the overall population had little influence on population level mortality. The study points to 
21 the necessity of considering both local and regional scale processes in analyses of density

22 dependence.

Key words

25

Spatial scale-dependency, density dependent distribution, demographic processes

Introduction

28

29

30

31

32

33

34

35

Density dependent demographic processes are thought to be an essential mechanism ensuring stability, resilience, and persistence in marine fish populations, which often experience large temporal variability in productivity (Turchin 1999, Berryman et al. 2002, Lande et al. 2002). However, demonstrating density dependence in marine fish populations is challenging (Hixon et al. 2002). The challenges may relate to the open dispersive phase, that decouples local reproduction and subsequent recruitment of juveniles to the population (Webster 2003) and the fact that marine processes are difficult to observe and hence, the available data are often confounded by high variance and potential bias (Hixon \& Carr 1997). An additional issue may be the mismatch between the spatial scale of population studies and the scale at which density dependent mechanisms act (Shima \& Osenberg 2003, Melbourne \& Chesson 2005, Einum \& Nislow 2005). This mismatch could explain why studies of density dependence in reef-associated species with well-defined habitat boundaries and high local densities often reveal significant results (Anderson 2001, Rose et al. 2001, Hixon \& Jones 2005), whereas effects of density dependence in species with more open population boundaries are less frequently detected (Myers 
42 \& Cadigan 1993a, b). Further, if the distribution of individual fish is density dependent (e.g. MacCalls basin theory, MacCall 1990), the combined effects of local density, local mortality and distribution can result in density dependence at population scale which differs substantially from that observed at local scale (Shima \& Osenberg 2003).

Sandeels Ammodytes spp. form an important link between lower and upper trophic levels in many shelf ecosystems (Hedd et al. 2006, Frederiksen et al. 2006, 2007, Eliasen et al. 2011). They are entirely dependent on coarse sandy sediments as they spend a considerable part of their nonfeeding periods buried (Winslade 1974a, b, c). The pelagic larvae can be transported considerable distances by currents before settling into sandy habitat (Potter \& Lough 1987, Proctor et al. 1998) but the exchange of post-settled sandeels between the sandy habitat patches is low (Jensen et al. 2011). The high site fidelity after settling into fragmented habitat combined with large fluctuations in densities (Wright et al. 2000, Holland et al. 2005) makes the lesser sandeel Ammodytes marinus in the North Sea an ideal case for investigating the effect of density dependence on population dynamics. Previous studies of the North Sea lesser sandeel have indicated the existence of density dependent processes at a regional scale (Arnott \& Ruxton 2002, van Deurs et al. 2009), acting concurrently with predation mortality, fishing pressure and climatically-induced changes in prey abundance to determine population size (Clausen et al. 2017, Lindegren et al. 2018). However, these studies did not investigate the role of density dependence acting within local habitat patches.

1 In the present study, we hypothesize that: (1) the spatial distribution of recruitment measured by 2 the catch rate of 1-year old fish depends on regional density in a given year, (2) local recruitment 3 depends on local density the previous year, (3) density dependent mortality occurs at a local scale 
and (4) the cumulated effect when scaling up to population level differs from the processes acting on a local scale. To investigate these hypotheses, we used a series of statistical models to analyse density dependent recruitment and mortality, taking into account both local and regional densities. The analysis was based on catch rates of lesser sandeel (Ammodytes marinus) in the North Sea commercial sandeel fishery and in a scientific survey at Shetland.

\section{Materials \& methods}

\section{Data}

The majority of the data was derived from a self-sampling programme on commercial sandeel fishing vessels. Vessels in the programme recorded the exact location and time of shooting and hauling of the trawl, and an estimate of the total weight of the catch in each individual haul. A sample of 0.5 to $1 \mathrm{~kg}$ fish was collected from each haul and frozen on board. In the laboratory, the lesser sandeel were length measured to nearest half $\mathrm{cm}$ below (Rindorf et al. 2016). Samples were assigned to fishing grounds based on the distance between the midpoint of the haul and the nearest fishing ground (Jensen et al. 2011) and hauls with midpoints closer than $1 \mathrm{~km}$ to a fishing ground were assumed to be taken on that fishing ground. All fishing grounds were located in the North Sea between $54^{\circ} \mathrm{N}$ and $57^{\circ} \mathrm{N}$ (fig. 1) and all participating vessels were Danish. The collection of samples started in 1999 with between 8 and 29 vessels participating each year (on average 15) until 2014, where the number of vessels increased to between 31 and 58 (on average 44). In 2012 and 2016, the fishery was restricted to a monitoring fishery in April before the main fishing season, and hence not strictly comparable to the catch rates from the remaining years. These years were therefore excluded from the analyses. 
In addition to the commercial data described above, data from a scientific survey conducted at

87 Shetland from 1985 to 2000 were also included (Cook 2004). During this period, sandeel at Shetland were subject to zero or very low fishing pressure and the data were therefore used to study the relationship between density and natural mortality. Data on regional stock size was derived from agreed sandeel assessments (ICES 2018).

Catch rate in numbers at age $a$ per minute fishing $\left(C_{a}\right.$, in units of sandeels caught $\left.\min ^{-1}\right)$ was estimated by combining estimated catch in kg per minute fishing with numbers per kg of each age group. The latter was estimated by applying separate age-length keys for each fishing ground and week where possible; otherwise data from within the same statistical rectangle $\left(1^{\circ} \mathrm{W}\right.$ times $\left.0.5^{\circ} \mathrm{N}\right)$ and two consecutive weeks were combined before fitting the age-length key. The age-length key analysis used the method described in (Rindorf \& Lewy 2001). In some hauls, the number of large fish was too low to provide reliable estimates of the number of fish older than age 1 . Hence, the number of data values for age 1 exceeded that for age 2 .

To avoid violating assumptions of the statistical regression models used, a sequence of transformations and statistical modelling was used. First, the variance of catch rates tends to increase with the mean (Pennington 1983). To address this, all catch rates were transformed by taking the natural log. Secondly, if the error of the independent variable is in the same order of magnitude as that of the dependent variable, parameter estimates in standard regression models may be considerably biased (Kendall \& Stuart 1979). This problem was addressed by using average catch rates across all samples in a given year whenever catch rates were used as an independent variable. This decreases the standard error of the independent variable compared to that of the dependent variable. Thirdly, the sampling design was highly unbalanced and using mean catch 
rates as the dependent variable in a standard linear regression would violate the assumption of constant variance of the observations. We used individual catch rates as observations in all analyses to accommodate the unbalanced sampling design and to assure that the variance of the dependent variable is considerably larger than that of the independent variable. Lastly, the data from a specific fishing ground, fishing vessel, or year are likely to be correlated due to e.g. local weather effects, skipper skills etc. To address this, random effect models were used throughout and the $r^{2}$ of the model using only fixed and both fixed and random effects given (Nakagawa \& Schielzeth 2013).

\section{Spatial distribution of recruitment depends on regional density in a given year}

118 The relationship between spatial distribution of recruitment measured by the catch rate of 1-year 119 old fish and density in the given year was investigated by relating the catch rates of 1-year old 120 sandeel on the individual fishing grounds to that of a central reference ground. This will reveal if 121 different grounds experience the same relative (regional) annual change in recruitment or if some 122 grounds exhibit greater changes than others. The analysis was performed using a random effects 123 model, where the central well-sampled fishing ground, North West Rough, was used as the 124 reference ground and catch rate of 1-year old fish was used as recruitment proxy:

126 Here, $\ln \hat{C}_{1, g, y, v}$ is the predicted log catch rate of 1-year olds of vessel $v$ at fishing ground $g$ in year $127 y, \ln \bar{C}_{1, N W R o u g h, y}$ is the average log catch rate of 1-year olds on North West Rough in the given 128 year and $k_{g}$ is the theoretical catch rate at fishing ground $g$ when $\ln \bar{C}_{1, N W R o u g h, y}$ is 1 . The slope $\gamma_{g}$ 129 describes the fishing ground specific relationship with density at the reference ground and the 
random effects of year/fishing ground and fishing vessel ID are contained within $\omega_{g, y} \in N\left(0, \sigma_{\omega}\right)$

131 and $\varphi_{v} \in N\left(0, \sigma_{\varphi}\right)$, respectively. If $y_{g}$ is close to one and $\sigma_{\omega}$ and $\sigma_{\varphi}$ are small, virtually all variation

132 is explained by the recruitment at the reference ground, North West Rough (no density

133 dependence). If $y_{g}$ values $>1$, there is positive density dependence at the fishing ground, and an

134 increased recruitment on the reference ground is accompanied by a higher than proportionally

135 increased recruitment at other grounds. In contrast, $y_{g}$ values between 0 and 1 are indicative of

136 negative density dependence at the fishing grounds, where an increased recruitment on the

137 reference ground is accompanied by a lower than proportionally increased recruitment at other

138 grounds. Lastly, if $y_{g}$ is close to zero and $\sigma_{\omega}$ and/or $\sigma_{\varphi}$ are large, the development in local

139 recruitment is independent of that recorded at the reference ground. Since $\gamma_{g}$ is estimated for

140 each fishing ground, it is possible that negative density dependence is detected on some grounds

141 and positive density dependence on others. The model was fitted to all data as well as to a subset

142 of data consisting only of fishing grounds within sandeel population area 1 (fig. 1). A similar model

143 was made for population area 4 (fishing grounds close to the coast of Scotland, fig. 1) using

144 Berwick Bank as the reference fishing ground. The areas are considered to contain separate

145 populations (ICES 2016) and hence correlation is expected within areas but not necessarily

146 between areas.

147 If recruitment to different fishing grounds is density dependent, the economic profitability of

148 different fishing grounds may vary with density leading to a relationship between catch rates and

149 stock size that differs from proportional at the regional scale (density dependent catchability). In

150 order to test for density dependent catchability at the regional level, the yearly average catch 
151

$\ln \hat{C}_{1, g, y, v}=k_{g}+\eta_{g} \ln R_{1, y}+\omega_{g, y}+\varphi_{v}$

rates of age 1 sandeel were compared to the number of age 1 fish on January $1^{\text {st }}$ estimated in the analytical assessment (ICES 2018) using a log-linear model:

154 where $\hat{C}_{1, g, y, v}$ is the predicted catch rate of age 1 sandeel of vessel $v$ at fishing ground $g$ in year $y$, the constant $k_{g}$ represents the average catch rate at the fishing ground at a theoretical abundance of 1 (not related to $k_{g}$ in eq. 1 ), $R_{1, y}$ is number of age 1 fish on January $1^{\text {st }}$ in year $y$ taken from the analytical assessment, and $\eta_{g}$ describes the ground-specific dependence of catch rates on $R_{1, y}$. $\omega_{g, y} \in N\left(0, \sigma_{\omega}\right)$ describes the random effect of year and fishing ground and $\varphi_{v} \in N\left(0, \sigma_{\varphi}\right)$ describes the random effect of vessel ID. For catchability to be density independent, $\eta_{g}$ must be one. If $\eta_{g}$ is larger than one, catch rates decrease faster than proportionally as abundance decreases (hyperdepletion, (Hilborn \& Walters 1992)). If $\eta_{g}$ is less than one, catch rates decrease slower than proportionally as abundance decreases (hyperstability, (Hilborn \& Walters 1992)). Temporal trends in catchability at age 1 was analysed by making $\eta_{g}$ a linear function of year and testing whether this improved model fit significantly.

\section{Local recruitment depends on local density the previous year (Hypothesis 2)}

167 Recruitment can be temporally density-dependent if the recruitment on a given fishing ground in a 168 given year depends on the recruitment to that specific ground in the preceding year. This type of 169 density dependent recruitment was tested using the following model: 
171 Here, $\ln \hat{C}_{1, g, y, v}$ is still the predicted log catch rate of 1-year olds of vessel $v$ at fishing ground $g$ in 172 year $y$ and $\ln \bar{C}_{1, g, y-1}$ is log catch rate of 1-year old fish (used as a proxy for recruitment) for a 173 given fishing ground in the preceding year $(y-1)$. The intercept $k_{y}$ describes the predicted catch 174 rate at a theoretical average recruitment in the preceding year equal to $1, \kappa_{g}$ describes the effect 175 of the recruitment in the preceding year and the random effects of year/fishing ground and fishing 176 vessel ID are again contained within $\omega_{g, y} \in N\left(0, \sigma_{\omega}\right)$ and $\varphi_{v} \in N\left(0, \sigma_{\varphi}\right)$, respectively. Note that 177 the density dependent effect was estimated for each fishing ground separately.

\section{Density dependent mortality occurs at local scale (Hypothesis 3)}

180 The density of a cohort will decrease exponentially from year $y$ to year $y+1$ as fish are removed by mortality, according to the population decay function:

$N_{a+1, y+1}=N_{a, y} e^{-z_{y}}$

183 Where $N_{a, y}$ is the number of fish in the population of a given age class $a$ at the beginning of the 184 year $y$ and $Z_{y}$ denotes the total mortality rate for a given year. Using catch rates as indicators of 185 abundance, we can adapt the above equation:

$\hat{C}_{2, y+1}=\frac{q_{2, y+1}}{q_{1, y}} \hat{C}_{1, y} e^{-Z_{y}}$

Hence, if the relative difference in catchability of the two age groups and mortality remain constant over time, the catch rate of a given cohort in a particular year is directly proportional to the catch rate of the same cohort in the preceding year. Note that when we use catch rates rather than abundance, catch rates of e.g. 2-year olds $\left(C_{2}\right)$ may exceed that of 1-year olds $\left(C_{1}\right)$ the year 
before if catchability of 2-year olds $\left(q_{2}\right)$ is higher than of 1-year olds $\left(q_{1}\right)$. If mortality is density dependent, $Z_{y}$ is a function of the population density in that year. Assuming that mortality is

193 linearly related to log abundance with the proportionality factor $\beta$, this relationship can be 194 described as:

$Z_{y}=Z_{0}+\beta \ln N_{1, y}=Z_{0}-\beta \ln q_{1, y}+\beta \ln \hat{C}_{1, y}$

Where $Z_{0}$ is the theoretical mortality at $\ln \hat{C}_{1, y}=\ln q_{1, y}$ or $\beta=0$. When inserting this relationship and taking the natural logarithm on both sides, we get

$\ln \hat{C}_{2, y+1}=k_{y+1}+(1-\beta) \ln \hat{C}_{1, y}$

where $k_{y+1}=\ln \left(\frac{q_{2, y+1}}{\left(q_{1, y}\right)^{1-\beta}}\right)-Z_{0}$

Estimates from the stock assessment of sandeel in area 1 indicate that the ratio $\frac{q_{2, y}}{q_{1, y-1}}$ is increasing over time (ICES 2018), and this was accounted for in the model based on the equation above:

$\ln \hat{C}_{2, \mathrm{~g}, y+1, v}=k_{0}+k_{1} y+\left(1-\beta_{g}\right) \ln \bar{C}_{1, \mathrm{~g}, y}+\omega_{g, y}+\varphi_{v}$ where $k_{0}=\ln \left(\frac{q_{2,2000}}{\left(q_{1,1999}\right)^{1-\beta}}\right)-Z_{0}, k_{1}=\Delta \ln \left(\frac{q_{2}}{\left(q_{1}\right)^{1-\beta}}\right)$ describes the annual change in the ratio of catchabilities, $\beta_{g}$ describes the density dependent effect of last year's geometric average catch rate of 1-year olds, $\ln \bar{C}_{1, y}$, on mortality at fishing ground $g$, allowing us to determine if mortality differs between high and low survival grounds as suggested by Shima and Osenberg (2003). $N\left(0, \sigma_{\omega}\right)$ and $\varphi_{v} \in N\left(0, \sigma_{\varphi}\right)$, respectively. Mortality is independent of density when $\beta=0$. If $\beta$ is greater than zero, mortality increases with density. $\beta$ was estimated at the two fishing grounds 
with 8 or more years of data (North West Rough and Southernmost Rough). Due to the very

211 limited catches of fish of age 3 and older, only mortality from 1-year olds to 2-year olds was

212 investigated. To allow comparison of mortality levels between fishing grounds, mortality indices

213 for fishing grounds with at least 5 years data were estimated assuming $\beta=0$ as $\ln \bar{C}_{2, y+1}-\ln \bar{C}_{1, y}$.

214 Catch rates from a scientific survey around Shetland was analysed using a slightly different model

215 without random effect terms and time trend in catchability:

216

$\ln \hat{C}_{a+1, y+1}=k_{0}+(1-\beta) \ln \bar{C}_{a, y}$

217 These simplifications were required since only one value per year was available and it is reasonable to assume that catchability in a scientific survey is constant over time. More ages were

219 available than in the commercial samples and the analysis therefore included ages 0 to 4 . Since

$220 \ln \bar{C}_{a, y}$ is observed with error, ordinary regression is not appropriate. Instead, Deming regression

221 was used to estimate $\beta$ assuming the error in the dependent and independent variable to be equal

222 (Linnet 1993). The 95\% confidence limits of $\beta$ were estimated using jackknife.

\section{Cumulated density dependent effects differ from the processes acting on a local scale} (Hypothesis 4)

226 Following the analyses of density dependence in recruitment and mortality, the predictions from

227 the two analyses were combined to assess the integrated effect of local density dependence in mortality and spatial distribution of recruitment on regional mortality (summed across local fishing grounds). Three different combinations were examined: 
1. Spatial distribution of recruitment depends on regional density and local mortality is independent of local density

2. Spatial distribution of recruitment is independent of regional density and local mortality depends on local density

3. Spatial distribution of recruitment depends on regional density and local mortality depends on local density

237 product of local density estimated from the relationship with density at North West Rough and the 238 surface area of the fishing ground, $A_{g}$ :

$239 \mathrm{I}_{1, g, y}=A_{g} e^{\left(k_{g}+\gamma_{g} \ln \bar{C}_{1, N W R o u g h, y}\right)}$

240 Where $k_{g}$ and $\gamma_{g}$ are estimated in model 1. For option 2, the ground specific index of abundance 241 was estimated as the ground specific median abundance index multiplied by area of the ground.

242 As the aim is to investigate the impact of the each of the density dependent components 243 distribution and mortality, the observed abundance at age 2 cannot be used as this includes both 244 effects. Instead, the index of abundance of 2-year old fish at each ground for this analysis was 245 estimated as $I_{2, g, y}=I_{1, g, y} \exp \left(-Z_{1, g, y}\right)$. For option 1 , the average mortality index at each ground, $246 Z_{1, g, y}$, was assumed equal to the observed $k_{0, g}=\ln \bar{C}_{a+1, y+1, g}-\ln \bar{C}_{a, y, g}$ averaged across years. 247 For options 2 and 3, the annual mortality index at a ground was assumed equal to $k_{0, g}-\beta \ln \bar{C}_{a, y, g}$ 248 where the value of $\beta$ was estimated in model 4.

249 The total mortality index across fishing grounds was estimated as: 
$250 \quad Z_{\text {pop }, y}=\ln \left(\sum_{g} I_{1, g, y}\right)-\ln \left(\sum_{g} I_{2, g, y}\right)$

251 This was compared to an index of total abundance of age 1 fish across fishing grounds estimated 252 as:

253

$I_{p o p, y}=\ln \left(\sum_{g} I_{1, g, y}\right)$

254 As the abundance and mortality are indices rather than absolute values, both are given relative to 255 the value at median density.

\section{Results}

\section{Spatial distribution of recruitment depends on regional density in a given year}

\section{(Hypothesis 1)}

260 The fixed effects model for fishing grounds in assessment area 1 explained $57 \%$ of the variation, 261 and the combined fixed and random effects explained 66\% (fig. S1 in supplementary material). The 262 standard deviation of the random effect of fishing ground and year (0.31) was much larger than 263 that of vessel ID (0.18), but smaller than the residual deviation (1.84). The fishing ground Lisborgs 264 Revle had a slope $\left(\gamma_{g}\right)>1$ (table 2). The remaining fishing grounds in assessment area 1 showed no 265 significant difference in $\gamma_{g}(\mathrm{P}=0.6031)$. The joint slope at these grounds was 0.62 (table 3$)$, which 266 was significantly different from both 0 and $1(P<0.001$ in both cases). Hence, when recruitment at 267 age 1 increased by $100 \%$ at North West Rough, recruitment at Lisborgs Revle increased by $155 \%$ 268 and recruitment at fishing grounds other than Lisborgs Revle increased by only 54\% (fig. 2). These 
density dependent differences in catch rates across grounds meant that when catch rates were low on average across all grounds (i.e. low regional population density), North West Rough and Lisborgs Revle catch rates were low relative to other grounds, while catch rates at these grounds were the highest observed when average catch rates were high (fig. 3). In spite of these differences, strong year-classes were detectable across all grounds as above average densities, while weak year-classes provided below average densities across all grounds (i.e. note the difference in scale in fig. 2).

Annual recruitment at fishing grounds in assessment areas 2 and 4 was not related to catch rates at North West Rough ( $\gamma_{g}$ not different from zero, $\mathrm{P}=0.0604$, fig. 3). However, catch rates at Wee Bankie were significantly related to those at Berwick Bank (area 4, $\mathrm{P}=0.0158$ ).

Catch rate in area 1 was highly correlated to abundance estimated from the analytical assessment $\left(P<0.0001, r^{2}\right.$ of fixed and random effects together $=59 \%$, (fig. 4 and fig. S2)). The estimated slope $\left(\eta_{g}\right)$ of the relationship between catch rate and abundance was 1.24 with a standard error of 0.13 , not significantly different between fishing grounds $(P=0.3355)$. The value is not significantly different from one $(\mathrm{P}=0.0718)$ and hence there was a non-significant tendency towards density dependent catchability at a population level. There was no significant trend over time in catch rate divided by stock abundance (i.e. index of catchability at age 1) $(P=0.1226)$.

\section{Local recruitment depends on local density the previous year (Hypothesis 2)}

Recruitment at age 1 to a given fishing ground was not significantly related to the recruitment in the previous year $(\mathrm{P}=0.1170)$. 


\section{Density dependent mortality occurs at local scale (Hypothesis 3)}

292 Only North West Rough and Southernmost Rough were sampled sufficiently to allow the 293 estimation of density dependence in mortality while seven grounds were sampled sufficiently to 294 allow the estimation of a ground specific mortality index (fig. 5 and 6). Among the seven grounds sampled, Lisborgs revle had the lowest mortality, S.W. Patch and Elbow Spit the highest while the remaining grounds had intermediate values. The catch rate at age 2 was highly related to catch rate of 1 -year old fish $(P<0.0001)$ and the model explained $51 \%$ and $65 \%$ of the variation by fixed and fixed plus random effects, respectively (fig. S3). The effect of year, $k_{1}$, was significantly positive $(P=0.0364)$, indicating that catch rates at age 2 increased over time even if catch rate of 1year old fish remained unchanged. $\beta$ was 0.19 and 0.21 at North West Rough and Southernmost Rough, respectively and neither $\beta$ nor $k_{0}$ differed between the two fishing grounds ( $\left.>>0.0795\right)$. The joint density dependent term $\beta$ was significantly positive $(\beta=0.21$, std $=0.09, \mathrm{P}=0.0218)$. The model used for the Shetland data revealed a common $\beta$ of 0.27 (std=0.07), significantly greater than $0(P=0.0003)$ (fig. 7). With this strength of density-dependence, the smallest average catch rate of 1-year olds at North West Rough resulted in a $230 \%$ higher catch rate when the fish were 2-year olds, corresponding to a higher catchability of 2-year olds compared to 1-year old fish masking the effects of mortality. In contrast, the largest average catch rate of 1-year olds at North West Rough resulted in $58 \%$ lower catch rate when the fish were 2-year olds, corresponding to an 8-time reduction in survival between the smallest and the largest year-class (assuming constant catchability at age). The density dependence at Shetland was sufficient to reduce the survival of the largest and smallest index by a factor 5 . This could potentially be contributing to the stabilization of the population by increasing mortality of large year-classes. 
Cumulated density dependent effects differ from the processes acting on a local scale

\section{(Hypothesis 4)}

While density dependent mortality led to increased mortality at higher densities (fig. 8, dark grey broken lines), density dependent distribution of recruitment to age 1 led to the opposite result, as the proportion of fish settling to recruit at age 1 at grounds showing high mortality decreased when the overall recruitment in the population was high (fig. 8, light grey dotted lines). Combining 320 the two for fishing grounds in the Dogger Bank area resulted in a mortality index, which was

321 virtually independent of abundance (solid black line in fig. 8). Excluding S. W. Patch, which had a 322 very high estimated mortality index and a very large area, changed the result so the combined

323 effect of density dependent recruitment and mortality was an increase in mortality with 324 abundance, acting to decrease fluctuations in stock abundance at age 2 compared to age 1. If we 325 assume that catchability of age 1 and 2 are equal, this corresponds to a reduction in survival from $32647 \%$ at the lowest observed abundance to $18 \%$ at the highest observed abundance. The results of 327 all density dependence investigations are summarised in table 4.

\section{Discussion}

330 The regional population processes of North Sea sandeel were a combination of density dependent 331 spatial distribution of recruitment on a regional scale and density dependent mortality on a local 332 scale. In years characterized by a large overall population, a large fraction of the population occurred at low mortality fishing grounds while local mortality increased. Depending on the 
balance between these two factors, this potentially leads to either increasing or decreasing mortality as abundance increases.

Sandeel recruitment in all areas increased as overall recruitment increased, but the increase was substantially greater at North West Rough and Lisborgs Revle. Consequently, the relative contribution of these grounds shifted from supporting the lowest sandeel densities in years where the overall population size was small to supporting the highest densities when the overall population size was large. This density dependence in the distribution of recruitment across fishing grounds does not follow the most commonly referenced distribution hypotheses. For example, the basin theory (MacCall 1990) and the theory on cryptic density dependence (Shima \& Osenberg 2003) predicts that high quality habitat is always occupied and exhibits the highest densities. This is not the case in our data, as the two grounds switch from having the lowest relative density to the highest relative density. Sutherland's (1983) theory of fish distribution, based on a different parametrization of the Ideal Free Distribution (Fretwell \& Lucas 1969), predicts that as the overall population size goes up, local densities throughout the population range increase proportionally.

348 However, this prediction does not match our results either. An alternative explanation for our 349 observations could be spatio-temporal variation in the environmental conditions for recruitment. 350 If oceanographic features, such as advection and retention, vary in different years, this might 351 affect recruitment of settling larvae by shaping the trophodynamic arena that regulate survival 352 through food availability and the physical settings that determine transport into and retention 353 within an area (Henriksen et al. 2018). For example, if the recruitment conditions such as food 354 availability and drift pattern are highly variable in the northwest corner of Dogger Bank but more 355 stable in other areas and large food availability only occurs in the northwest corner of Dogger Bank when there is a high food supply overall, this could explain the greater variation at North 
West Rough and Lisborgs Revle. Alternatively, the number of sandeel dying from predation before age 1 in these two areas is a constant number rather than a constant fraction. This would lead to a greater mortality up to age 1 at low abundance than at high abundance and could be the result of a predator stock which remains approximately constant and is capable of feeding at approximately the same rate regardless of overall sandeel density (i.e. limited by handling time rather than search time (Stephens \& Krebs 1986)).

The distribution of sandeel recruitment was not affected by the density of the previous cohort. This is in contrast to studies on sandeel abundances reporting negative correlations between the recruitment in a given year and that in the previous (Arnott \& Ruxton 2002, van Deurs et al. 2009, Lindegren et al. 2018). It is possible that the residual variation in our data was too large for the density dependent effect to be detected at the local scale. Alternatively, the autocorrelation seen in earlier studies was caused by factors relating to the assessment model output used. If the commercial fishery targets fishing grounds with high abundance of specific cohorts, this can introduce an overrepresentation of these cohorts and an underrepresentation of the adjacent cohorts in the regional catch data, leading to the impression that there is negative autocorrelation at the population level, even though there is no autocorrelation at the local scale.

Density dependent mortality substantially reduced the difference between large and small local cohorts at the local level, potentially contributing to the stability of local aggregations. The density dependent mortality seemed to be a result of predation rather than fishing, as it was present at approximately the same level in unfished (Shetland) and fished areas (North West Rough and 377 Southernmost Rough). Density dependent natural mortality of fish such as damselfish (Dascyllus 378 flavicaudus) and bridled goby (Coryphopterus glaucofraenum) acts through exposing individuals to 
higher predation rates once the carrying capacity of an area has been reached (Forrester \& Steele 2004, Schmitt \& Holbrook 2007). In the case of sandeel, carrying capacity may refer to the availability of suitable burying substrate rather than to refuges as in reef fish (Hobson 1986).

Different substrates may offer different overwintering survival or increased food competition may lead to delayed onset of the overwintering period, increasing predation mortality (van Deurs et al. 2011). There was no significant difference in the level of density dependent mortality at the three sites examined, indicating that either the sites are similar in quality or the factors inducing density dependence are not related to quality of the sites as found for coral reef fish, such as Thalassoma Hardwicke (Shima \& Ostenberg 2003).

Density dependence in natural mortality occurs if natural predators switch between different prey types according to their abundance, either by changing their consumption or by exhibiting an aggregative response (Murdoch et al. 1975, Anderson 2001). Large-scale studies of the diet of predatory fish in the North Sea and Celtic Sea have generally failed to produce evidence of more than proportional increases in consumption of individual predators with increasing prey density (Pinnegar et al. 2003, Rindorf \& Gislason 2005, Rindorf et al. 2006). However, as areas of sandeel habitat are characterised by highly stationary features (gravelly substrate and limited depth range), they can potentially be targeted accurately by aggregating natural predators (Temming et al. 2004, van der Kooij et al. 2008, Engelhard et al. 2008). Hence, it is possible that extensions in the period in which the predators feed on sandeel and aggregation of predators in areas with high densities of sandeel lead to the observed density dependence of mortality from age 1 to 2 .

If the fishery optimises revenue by seeking out the highest catch rates, the density dependent distribution of recruitment will lead to a widespread fishery with low catch rates and little fishing 
401

activity at North West Rough and Lisborgs Revle when the overall population is small. When the population is large, the fishery will exhibit high catch rates and concentrate at North West Rough and Lisborgs Revle. This general pattern seems to be confirmed by the distribution of commercial catches in 2003-2005, where abundance was low compared to later years (ICES 2018). The generally reported form of density dependence of catch rates is hyperstability, where catch rates decrease slower than abundance (Saville \& Bailey 1980, Winters \& Wheeler 1985, Beverton 1990).

This has been suggested to be a major cause of overfishing (Erisman et al. 2011). In contrast, the pattern in our data is likely to lead to hyperdepletion of catch rates, where catch rates decrease faster than fish abundance at a regional scale. This is also indicated by the analysis of density dependent catchability, where the slope $(\eta)$ (eq. 2 ) was estimated to be 1.24 , consistent with hyperdepletion. Alternatively, local catchability depends on local density. If this is the case, it would bias the analysis of density dependence of mortality. However, to produce the impression of mortality increasing with density where no such underlying process exists, catchability for age 1 must increase with density more than that of age 2 . This is consistent with hyperdepletion for age 1 rather than the more commonly reported hyperstability. It is not clear by which process the catchability at a local fishing ground would increase with density. The opposite relationship however, where catchability decreases with increasing stock size is consistent with fisheries targeting prime habitat into which the fish are aggregating to a greater degree when stock size is low.

In summary, the population dynamics of lesser sandeel in the North Sea rely on a mosaic of local habitats determining density dependence at the regional population level. Local density dependent mortality led to increasing mortality at higher densities. Concurrently, density dependent distribution of recruitment led to a shift in distribution towards low mortality fishing 
424 grounds when recruitment at the regional scale was high. As a result, hyperdepletion of catch

425 rates was more likely than hyperstability. Combining the two density dependent effects for fishing

426 grounds in the Dogger area resulted in a mortality index, which was virtually independent of

427 abundance. Our study demonstrated the necessity of considering both local and regional

428 processes in analyses of density dependence (Shima \& Osenberg 2003, Einum \& Nislow 2005): had

429 the analysis considered only local density dependent effects on mortality, the conclusion of the

430 study would have been in complete opposition to an analysis considering only density dependent

431 effects on the spatial distribution of recruitment.

432

\section{Acknowledgements}

434 We are deeply grateful for the effort of the fishing skippers, who collected the data and placed

435 them at our disposal, to the Danish Fishing Producers Organization and the Danish Pelagic

436 Producers Organization that supported the work and to Stina B. S. Hansen and the laboratory

437 technicians who worked up the thousands of length samples. The work was funded by the EMFF 438 project 'Forvaltningsmodeller for fiskebestande' 33113-B-16-080.

\section{References}

441 Anderson TW (2001) Predator responses, prey refuges, and density-dependent mortality of marine fish. Ecology 82:245-257

443 Arnott SA, Ruxton GD (2002) Sandeel recruitment in the North Sea: demographic, climatic and trophic effects. Mar Ecol Prog Ser 238:199-210 
Berryman AA, Lima Arce M, Hawkins BA (2002) Population regulation, emergent properties, and a requiem for density dependence. Oikos 99:600-606

Beverton RJH (1990) Small marine pelagic fish and the threat of fishing; are they endangered? J Fish Biol 37:5-16

Clausen LW, Rindorf A, Deurs M van, Dickey-Collas M, Hintzen NT (2017) Shifts in North Sea forage fish productivity and potential fisheries yield. J Appl Ecol 55:1092-1101

Cook R (2004) Estimation of the age-specific rate of natural mortality for Shetland sandeels. ICES J Mar Sci 61:159-164

Deurs M van, Hal R van, Tomczak MT, Jónasdóttir SH, Dolmer P (2009) Recruitment of lesser sandeel Ammodytes marinus in relation to density dependence and zooplankton composition. Mar Ecol Prog Ser 381:249-258

Deurs M van, Hartvig M, Steffensen JF (2011) Critical threshold size for overwintering sandeels (Ammodytes marinus). Mar Biol 158:2755-2764

Einum S, Nislow KH (2005) Local-scale density-dependent survival of mobile organisms in continuous habitats: an experimental test using Atlantic salmon. Oecologia 143:203-210

Eliasen K, Reinert J, Gaard E, Hansen B, Jacobsen J, Grønkjær P, Christensen J (2011) Sandeel as a link between primary production and higher trophic levels on the Faroe shelf. Mar Ecol Prog Ser 438:185-194

Engelhard GH, Blanchard JL, Pinnegar JK, Kooij J van der, Bell ED, Mackinson S, Righton DA (2013) Body condition of predatory fishes linked to the availability of sandeels. Mar Biol 160:299- 
Engelhard G, Kooij J van der, Bell E, Pinnegar J, Blanchard J, Mackinson S, Righton D (2008) Fishing mortality versus natural predation on diurnally migrating sandeels Ammodytes marinus. Mar Ecol Prog Ser 369:213-227

Erisman BE, Allen LG, Claisse JT, Pondella DJ, Miller EF, Murray JH (2011) The illusion of plenty: hyperstability masks collapses in two recreational fisheries that target fish spawning aggregations (C Walters, Ed.). Can J Fish Aquat Sci 68:1705-1716

Forrester GE, Steele MA (2004) Predators, prey refuges, and the spatial scaling of densitydependent prey mortality. Ecology 85:1332-1342

Frederiksen M, Edwards M, Richardson AJ, Halliday NC, Wanless S (2006) From plankton to top predators: bottom-up control of a marine food web across four trophic levels. J Anim Ecol 75:1259-1268

Frederiksen M, Furness R, Wanless S (2007) Regional variation in the role of bottom-up and topdown processes in controlling sandeel abundance in the North Sea. Mar Ecol Prog Ser 337:279-286

Fretwell SD, Lucas HL (1969) On territorial behavior and other factors influencing habitat distribution in birds. Acta Biotheor 19:16-36

Hedd A, Bertram D, Ryder J, Jones I (2006) Effects of interdecadal climate variability on marine trophic interactions: rhinoceros auklets and their fish prey. Mar Ecol Prog Ser 309:263-278

Henriksen O, Christensen A, Jonasdottir S, MacKenzie B, Nielsen K, Mosegård H, Deurs M van 
(2018) Oceanographic flow regime and fish recruitment: reversed circulation in the North Sea coincides with unusually strong sandeel recruitment. Mar Ecol Prog Ser 607:187-205

Hilborn R, Walters CJ (1992) Quantitative Fisheries Stock Assessment: Choice, Dynamics and Uncertainty. Springer US

Hixon MA, Carr MH (1997) Synergistic predation, density dependence, and population regulation in marine fish. Science (80- ) 277:946-949

Hixon MA, Jones GP (2005) Competition, predation, and density-dependent mortality in demersal marine fishes. Ecology 86:2847-2859

Hixon MA, Pacala SW, Sandin SA (2002) Population regulation: Historical context and contemporary challenges of open vs. closed systems. Ecology 83:1490-1508

Hobson ES (1986) Predation on the pacific sand lance, Ammodytes hexapterus (Pisces: Ammodytidae), during the Transition between Day and Night in Southeastern Alaska. Copeia $1986: 223$

Holland G, Greenstreet S, Gibb I, Fraser H, Robertson M (2005) Identifying sandeel Ammodytes marinus sediment habitat preferences in the marine environment. Mar Ecol Prog Ser 303:269-282

ICES (2016) Report of the Benchmark Workshop on Sandeel (WKSand 2016). Bergen, Norway

ICES (2018) Herring Assessment Working Group for the Area South of 62 deg N (HAWG). Copenhagen, Denmark

Jensen H, Rindorf A, Wright PJ, Mosegaard H (2011) Inferring the location and scale of mixing 

$68: 43-51$

Kendall M, Stuart A (1979) The advanced theory of statistics: Inference and relationship, 4th edn. Charles Griffin, London

Kooij J van der, Scott BE, Mackinson S (2008) The effects of environmental factors on daytime sandeel distribution and abundance on the Dogger Bank.

Lande R, Engen S, Saether B-E, Filli F, Matthysen E, Weimerskirch H (2002) Estimating density dependence from population time series using demographic theory and life-history data. Am Nat 159:321-37

514 Lindegren M, Deurs M Van, MacKenzie BR, Worsoe Clausen L, Christensen A, Rindorf A (2018) Productivity and recovery of forage fish under climate change and fishing: North Sea sandeel

MacCall AD (1990) Dynamic Geography of Marine Fish Populations. University of Washington Press, Seattle

Melbourne BA, Chesson P (2005) Scaling up population dynamics: integrating theory and data. Oecologia 145:178-186

521 Murdoch WW, Avery S, Smyth MEB (1975) Switching in Predatory Fish. Ecology 56:1094-1105

Myers RA, Cadigan NG (1993a) Is juvenile natural mortality in marine demersal fish variable? Can J 
526 Nakagawa S, Schielzeth H (2013) A general and simple method for obtaining $R^{2}$ from generalized 527 linear mixed-effects models (RB O'Hara, Ed.). Methods Ecol Evol 4:133-142

528 Pennington M (1983) Efficient estimators of abundance, for fish and plankton surveys. Biometrics 529 39:281

530 Pinnegar JK, Trenkel VM, Tidd AN, Dawson WA, buit MH Du (2003) Does diet in Celtic Sea fishes reflect prey availability? J Fish Biol 63:197-212

532 Potter DC, Lough RG (1987) Vertical Distribution and Sampling Variability of Larval and Juvenile 533 Sand Lance (Ammodytes sp.) on Nanutcket Shoals and Georges Bank*. J Northwest Atl Fish Sci

Proctor R, Wright PJ, Everitt A (1998) Modelling the transport of larval sandeels on the north-west 536 European shelf. Fish Oceanogr 7:347-354

Rindorf A, Gislason H (2005) Functional and aggregative response of North Sea whiting. J Exp Mar 538 Bio Ecol 324:1-19

Rindorf A, Gislason H, Lewy P (2006) Prey switching of cod and whiting in the North Sea. Mar Ecol 540 Prog Ser 325:243-253

541 Rindorf A, Lewy P (2001) Analyses of length and age distributions using continuation-ratio logits. Can J Fish Aquat Sci 58:1141-1152

543 Rindorf A, Wright PJ, Jensen H, Maar M (2016) Spatial differences in growth of lesser sandeel in 544 the North Sea. J Exp Mar Bio Ecol 479:9-19 
Rose KA, Cowan JH, Winemiller KO, Myers RA, Hilborn R (2001) Compensatory density dependence in fish populations: importance, controversy, understanding and prognosis. Fish Fish 2:293-327

Saville A, Bailey RS (1980) The assessment and management of the herring stocks in the North Sea and to the west of Scotland. Rapp Proces Verbaux des Reun 177:112-142

Schmitt RJ, Holbrook SJ (2007) The scale and cause of spatial heterogeneity in strangth of temporal density dependence. Ecology 88:1241-1249

Shima JS, Osenberg CW (2003) Cryptic Density Dependence: Effects of Covariation between Density and Site Quality in Reef Fish. Ecology 84:46-52

Stephens DW, Krebs JR, (1986) Foraging Theory. 1st ed. Monographs in Behavior and Ecology. Princeton University Press. ISBN 9780691084428.

Sutherland WJ (1983) Aggregation and the 'Ideal Free’ Distribution. J Anim Ecol 52:821

Temming A, Gotz S, Mergardt N, Ehrich S (2004) Predation of whiting and haddock on sandeel: aggregative response, competition and diel periodicity. J Fish Biol 64:1351-1372

\section{Turchin P (1999) Population regulation: A synthetic view. Oikos 84:153}

Webster MS (2003) Temporal density dependence and population regulation in marine fish. Ecology 84:623-628

Winslade P (1974a) Behavioural studies on the lesser sandeel Ammodytes marinus (Raitt) I. The effect of food availability on activity and the role of olfaction in food detection. J Fish Biol $6: 565-576$ 
565 Winslade P (1974b) Behavioural studies on the lesser sandeel Ammodytes marinus (Raitt) II. The 566 effect of light intensity on activity. J Fish Biol 6:577-586

567 Winslade P (1974c) Behavioural studies on the lesser sandeel Ammodytes marinus (Raitt) III. The 568 effect of temperature on activity and the environmental control of the annual cycle of $569 \quad$ activity. J Fish Biol 6:587-599

570 Winters GH, Wheeler JP (1985) Interaction between stock area, stock abundance, and catchability $571 \quad$ coefficient. Can J Fish Aquat Sci 42:989-998

572 Wright PJ, Jensen H, Tuck I (2000) The influence of sediment type on the distribution of the lesser $573 \quad$ sandeel, Ammodytes marinus. J Sea Res 44:243-256

574 
577 Table 1. Overview of models and density dependent terms used. In the following, $k$ is used to

578 denote a constant in the specific model and hence, though $k$ appears in several models, the

579 estimate of $k$ differs in each case.

\begin{tabular}{|c|c|c|c|}
\hline Hypothesis & Model & $\begin{array}{l}\text { Density dependence } \\
\text { analysed }\end{array}$ & Tests performed \\
\hline 1 & $\begin{array}{l}\ln \hat{C}_{1, g, y, v}=k_{g}+\gamma_{g} \ln \bar{C}_{1, N W R o u g h, y}+ \\
\omega_{g, y}+\varphi_{v}\end{array}$ & $\begin{array}{l}\text { The regional effect of } \\
\text { recruitment to North } \\
\text { West Rough (used as } \\
\text { reference fishing ground) } \\
\text { on the recruitment to } \\
\text { other fishing grounds. }\end{array}$ & $\begin{array}{l}\gamma_{g} \neq 0 \\
\gamma_{g} \neq 1\end{array}$ \\
\hline 1 & $\begin{array}{l}\ln \hat{C}_{1, g, y, v}=k_{g}+\eta_{g} \ln R_{1, y}+\omega_{g, y}+ \\
\varphi_{v} \quad \text { (2) }\end{array}$ & $\begin{array}{l}\text { The regional effect of } \\
\text { population abundance of } \\
\text { age } 1 \text { fish on the catch } \\
\text { rates of age } 1 \text { fish on the } \\
\text { individual fishing } \\
\text { grounds. }\end{array}$ & $\begin{array}{l}\eta_{g} \neq 0 \\
\eta_{g} \neq 1\end{array}$ \\
\hline 2 & $\begin{array}{l}\ln \hat{C}_{1, g, y, v}=k_{y, g}+\kappa_{g} \ln \bar{C}_{1, g, y-1}+ \\
\omega_{g, y}+\varphi_{v}\end{array}$ & $\begin{array}{l}\text { Dependence of local } \\
\text { recruitment in year } y \text { on } \\
\text { local recruitment in the }\end{array}$ & $\begin{array}{l}\kappa_{g} \neq 0 \\
\kappa_{g} \neq 1\end{array}$ \\
\hline
\end{tabular}




\begin{tabular}{|l|l|l|c|}
\hline & & previous year to the & \\
\hline 3 & $\ln \hat{C}_{2, \mathrm{~g}, y+1, \mathrm{v}}=k_{0}+k_{1} y+(1-$ & same fishing ground. & \\
& $\left.\beta_{g}\right) \ln \bar{C}_{1, \mathrm{~g}, y}+\omega_{g, y}+\varphi_{v} \quad(4)$ & mortality on local cohort & \\
& & density. & \\
\hline
\end{tabular}

580

581 
Table 2. Parameter estimates of the model $\ln \hat{C}_{1, g, y}=k_{0, g}+\gamma_{g} \ln \bar{C}_{1, N W R o u g h, y}+\omega_{g, y}+$

$583 \varphi_{v}$ describing the relationship between catch rates of 1-year olds at North West Rough and other

584 fishing grounds in assessment area 1. Significant probabilities (P) are in bold. $\mathrm{N}$ denotes number of

585 observations used, Year denotes number of years where data were available from that fishing

586 ground.

\begin{tabular}{|c|c|c|c|c|c|c|c|}
\hline Fishing ground & $\begin{array}{l}\text { Ass. } \\
\text { area }\end{array}$ & $\mathrm{N}$ & $\begin{array}{l}\text { Year } \\
\text { s }\end{array}$ & $\gamma_{g}$ & $\mathrm{P}(\gamma=0)$ & $\begin{array}{l}k_{0, g} \text { in } \\
\text { reduced } \\
\text { model }\end{array}$ & $\begin{array}{l}\gamma_{g} \text { in } \\
\text { reduced } \\
\text { model }\end{array}$ \\
\hline Lisborgs Revle & 1 & 313 & 11 & $1.35(0.13)$ & $<0.0001$ & $\begin{array}{l}-4.07 \\
(1.12)\end{array}$ & $1.35(0.12)$ \\
\hline Stenkanten & 1 & 124 & 11 & $0.74(0.10)$ & $<0.0001$ & $3.15(0.41)$ & $0.62(0.04)$ \\
\hline Rute 18 & 1 & 61 & 7 & $0.72(0.13)$ & $<0.0001$ & $2.88(0.42)$ & $0.62(0.04)$ \\
\hline $\begin{array}{l}\text { Southernmost } \\
\text { Rough }\end{array}$ & 1 & 234 & 14 & $0.67(0.09)$ & $<0.0001$ & $3.61(0.40)$ & $0.62(0.04)$ \\
\hline S. W. Patch & 1 & 169 & 11 & $0.49(0.10)$ & $<0.0001$ & $3.91(0.39)$ & $0.62(0.04)$ \\
\hline Sorel & 1 & 115 & 7 & $0.78(0.30)$ & 0.0093 & $3.47(0.47)$ & $0.62(0.04)$ \\
\hline Outer Well & 1 & 85 & 6 & $0.48(0.17)$ & 0.0057 & $4.05(0.44)$ & $0.62(0.04)$ \\
\hline Elbow Spit & 1 & 220 & 10 & $0.62(0.12)$ & $<0.0001$ & $3.83(0.43)$ & $0.62(0.04)$ \\
\hline Tail End & 1 & 94 & 8 & $0.55(0.10)$ & $<0.0001$ & $3.92(0.41)$ & $0.62(0.04)$ \\
\hline
\end{tabular}


Table 3. Proportion of individuals found in the Dogger Bank area present at each fishing ground.

\begin{tabular}{|c|c|c|c|c|c|}
\hline $\begin{array}{l}\text { Fishing } \\
\text { ground }\end{array}$ & Area $(\mathrm{km} 2)$ & $\begin{array}{l}\text { Average } \\
\ln \hat{C}_{1, y-1^{-}} \\
\ln \hat{C}_{2, y}\end{array}$ & $\begin{array}{l}\text { Proportion of } \\
\text { all at } \\
\text { minimum } \\
\text { density at } \\
\text { North West } \\
\text { Rough }\end{array}$ & $\begin{array}{l}\text { Proportion of } \\
\text { all at median } \\
\text { density at } \\
\text { North West } \\
\text { Rough }\end{array}$ & $\begin{array}{l}\text { Proportion of } \\
\text { all at } \\
\text { maximum } \\
\text { density at } \\
\text { North West } \\
\text { Rough }\end{array}$ \\
\hline Lisborgs Revle & 250 & 0.59 & 0.000 & 0.030 & 0.129 \\
\hline N.W. Rough & 593 & 1.28 & 0.018 & 0.192 & 0.367 \\
\hline $\begin{array}{l}\text { Southernmost } \\
\text { Rough }\end{array}$ & 204 & 1.64 & 0.048 & 0.085 & 0.074 \\
\hline Stenkanten & 216 & 1.79 & 0.023 & 0.060 & 0.062 \\
\hline S. W. Patch & 1285 & 2.76 & 0.911 & 0.634 & 0.368 \\
\hline
\end{tabular}

590 
Table 4. Summary of results

\begin{tabular}{|c|c|c|}
\hline $\begin{array}{l}\text { Hypothesis } \\
\text { number }\end{array}$ & Density dependence analysed & Tests results \\
\hline 1 & $\begin{array}{l}\text { The regional effect of the recruitment } \\
\text { to North West Rough (used as } \\
\text { reference fishing ground) on the } \\
\text { recruitment to other fishing grounds. }\end{array}$ & $\begin{array}{l}\text { Sandeel area 1: } \\
\gamma_{g}>1 \text { at Lisborgs Revle }(\mathrm{P}=0.0012) . \\
\text { Remaining fishing grounds had } 0<\gamma_{g}<1 \\
(\mathrm{P}<00001 \text { in both cases }) .\end{array}$ \\
\hline 1 & $\begin{array}{l}\text { The regional effect of population } \\
\text { abundance of age } 1 \text { fish on the catch } \\
\text { rates of age } 1 \text { fish on the individual } \\
\text { fishing grounds. }\end{array}$ & $\begin{array}{l}\eta_{g} \text { was significantly different from zero } \\
(P<0.0001) \text { but not significantly } \\
\text { different from } 1(P=0.0718)\end{array}$ \\
\hline 2 & $\begin{array}{l}\text { Dependence of local recruitment in } \\
\text { year } y \text { on local recruitment in the } \\
\text { previous year to the same fishing } \\
\text { ground. }\end{array}$ & $\begin{array}{l}\text { No significant effect of local } \\
\text { recruitment the previous year } \\
(P=0.1170, \kappa=0)\end{array}$ \\
\hline 3 & $\begin{array}{l}\text { Dependence of local mortality on local } \\
\text { cohort density. }\end{array}$ & $\begin{array}{l}\text { N. W. Rough and Southernmost Rough: } \\
\beta \text { significantly greater than zero } \\
(\beta=0.21, \mathrm{P}=0.0218) \text {, indicating that } \\
\text { mortality increased with increasing } \\
\text { density. } \\
\text { Shetland: } \beta \text { significantly greater than } \\
\text { zero }(\beta=0.27, \mathrm{P}=0.0003) \text {, indicating }\end{array}$ \\
\hline
\end{tabular}




\begin{tabular}{|l|l|l|}
\hline & & that mortality increased with increasing \\
density.
\end{tabular}

593

594 


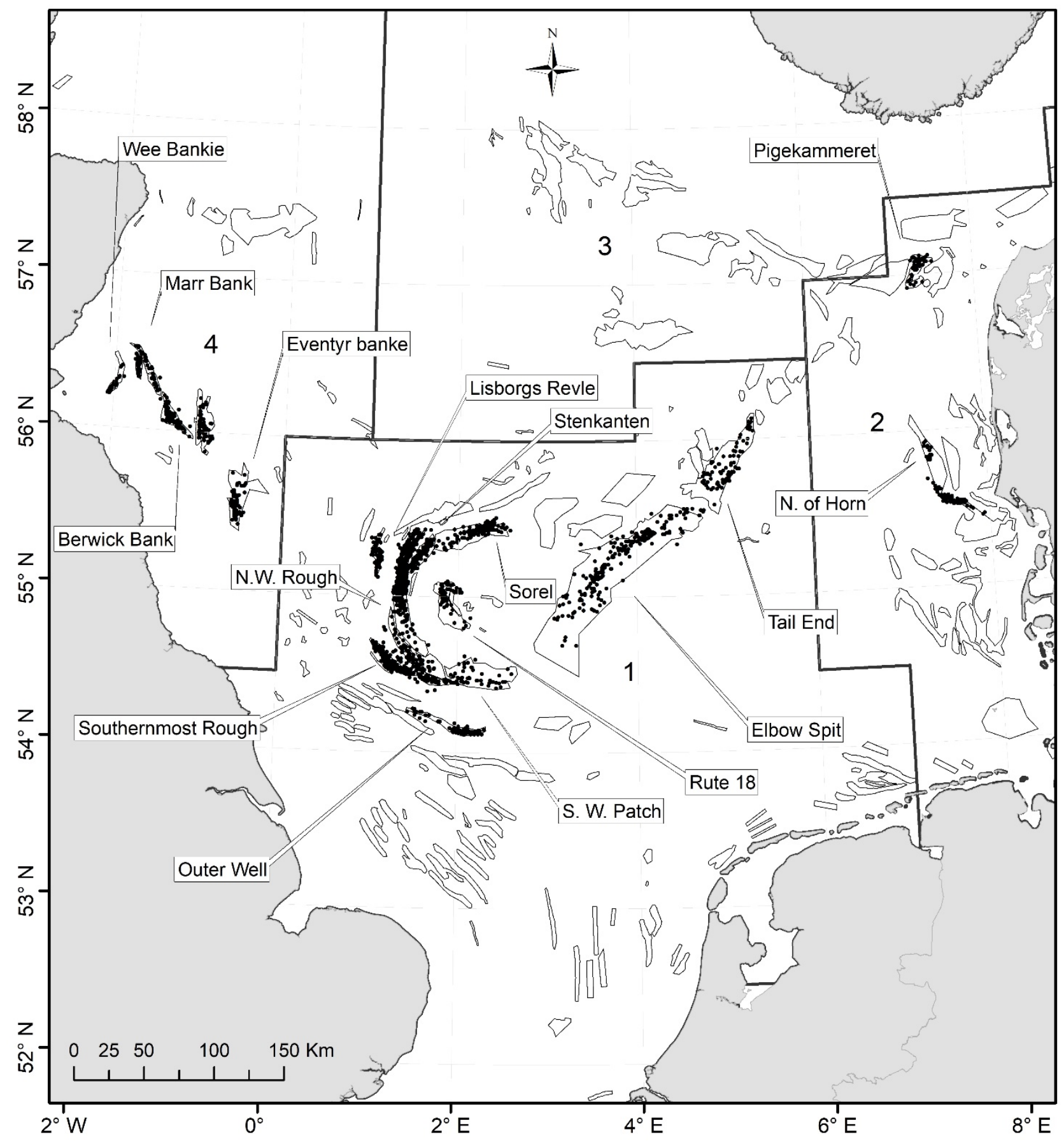

Fig. 1. Named fishing grounds and numbered sandeel areas referred to in the study. 
600

601
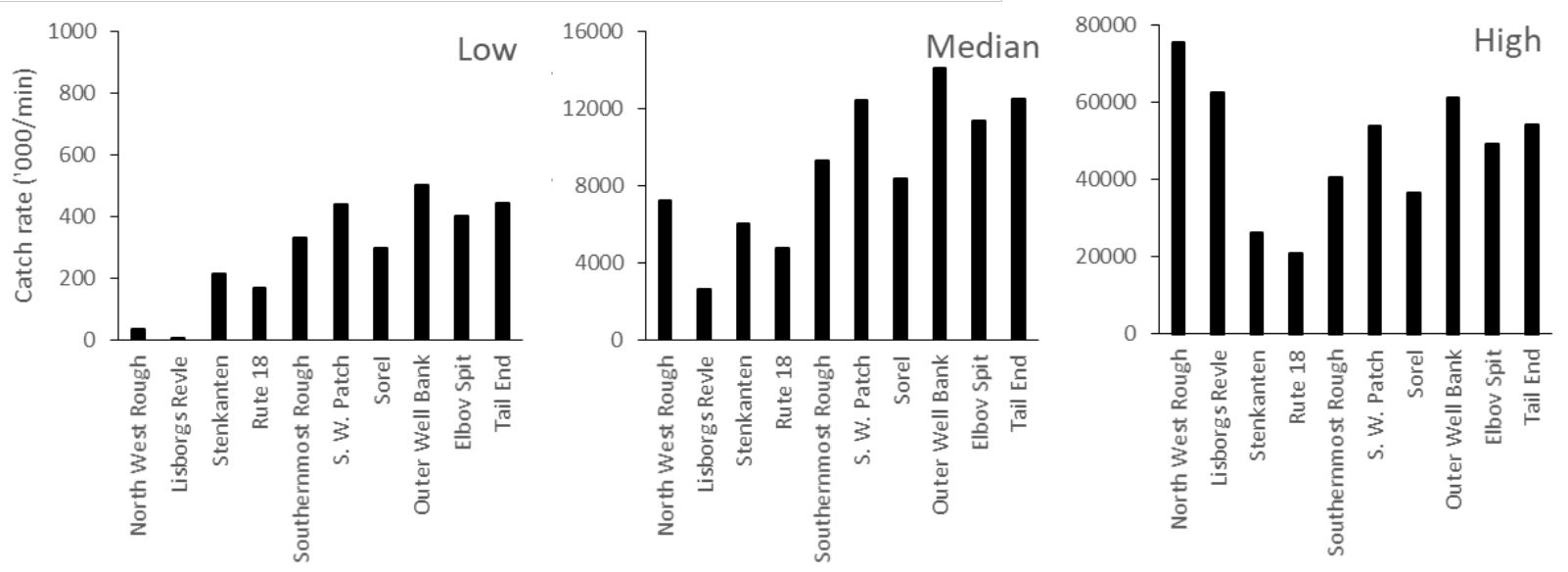

602 Fig. 2. Catch rates by fishing ground in area 1 at low, median and high densities at North West

603 Rough. Note difference in scale of the three plots. Fishing grounds are ordered according to

604 increasing distance to North West Rough. Catch rates did not differ significantly between fishing 605 grounds more distant than Rute 18. 

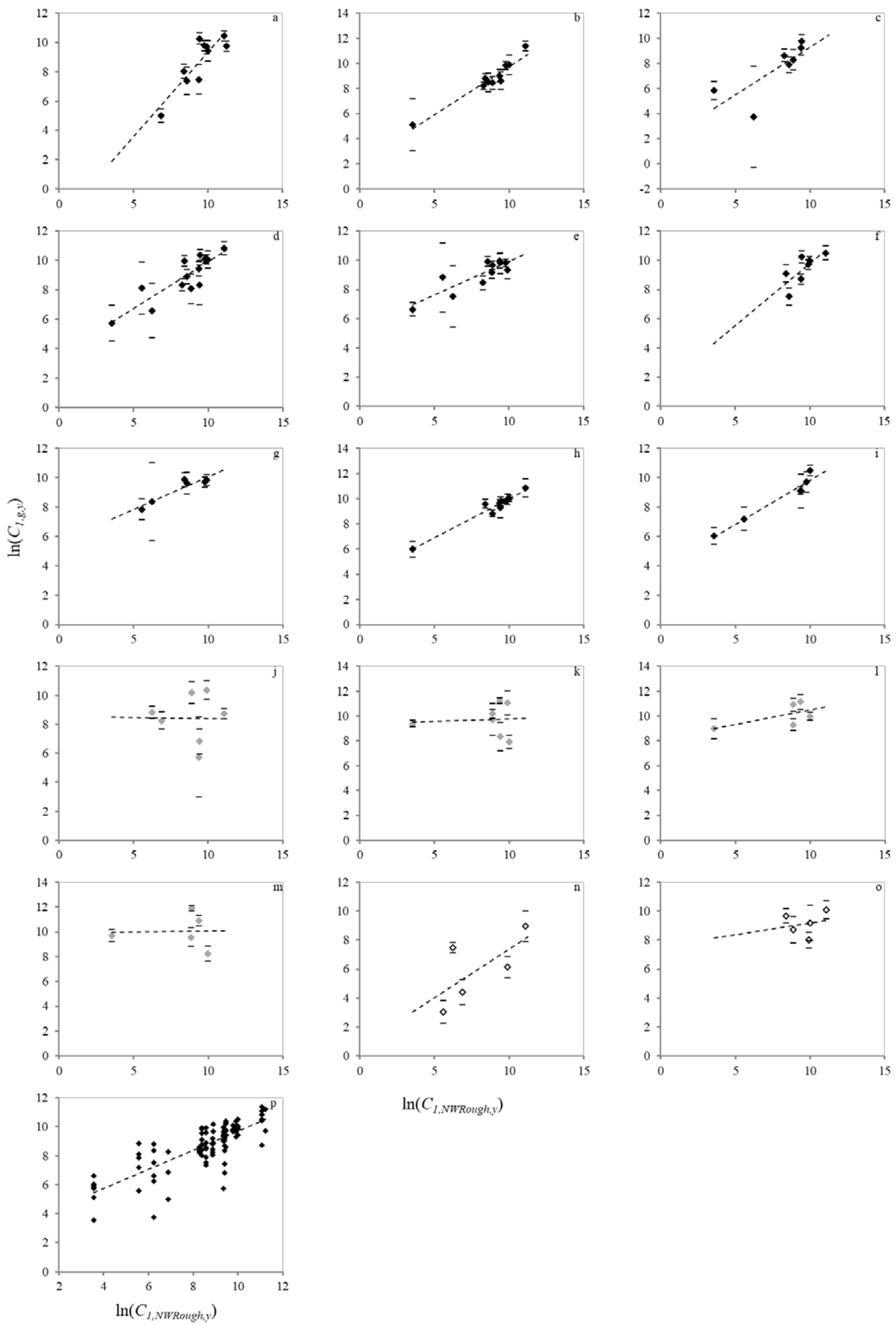

assessment in area $1\left(10^{9}\right)$. Hatched line shows the predicted average catch rate.

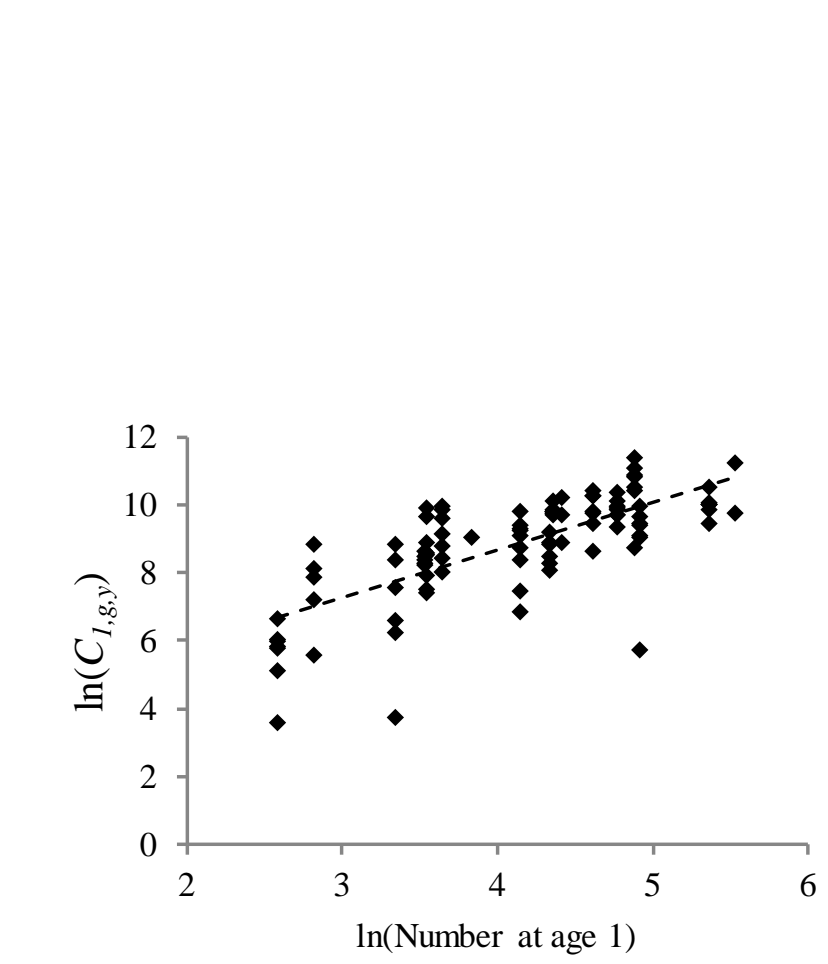

Fig. 4. Catch rates at all grounds as function of number of 1-year olds according to the ICES

Fig. 3. Average catch rate of 1 -year olds ('000/min) at 14 fishing grounds as a function of average catch rate at N. W. Rough. Fishing grounds are ordered according to distance to North West Rough, with letters higher in the alphabet indicating more distant fishing grounds: In assessment area 1 (black diamonds), Lisborgs Revle (a), Stenkanten (b), Rute 18 (c), Southernmost Rough (d), S.W. Patch (e), Sorel (f), Outer Well Bank (g), Elbow Spit (h), Tail End (i). In assessment areas 4 (grey diamonds), Eventyr Banke (j), Berwick Bank (k), Marr Bank (I), Wee Bankie (m), and in 2 (open diamonds), N. of Horn ( $\mathrm{n}$ ) and Pigekammeret (o). All fishing grounds in assessment area 1 plotted in one panel are also shown (p). Each symbol represents one year, bars indicate confidence limits of the mean, broken lines are ground specific regressions. 

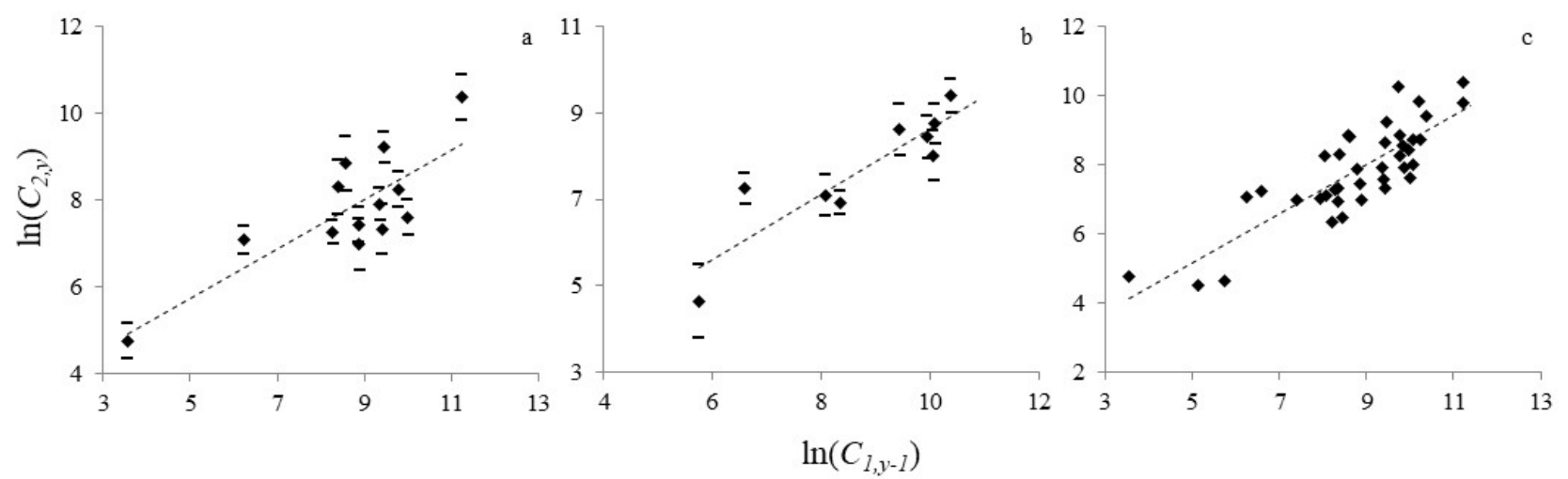

624 Fig. 5. Average log catch rate (catch in numbers per minute) in the current year of 2-year olds as a 625 function of average log catch rate of 1-year olds the preceding year. N. W. Rough (a),

626 Southernmost Rough (b) and all fishing grounds with at least 5 years of data (c). Horizontal lines 627 represent 95\% confidence limits of the mean, lines are ground specific average predictions. 


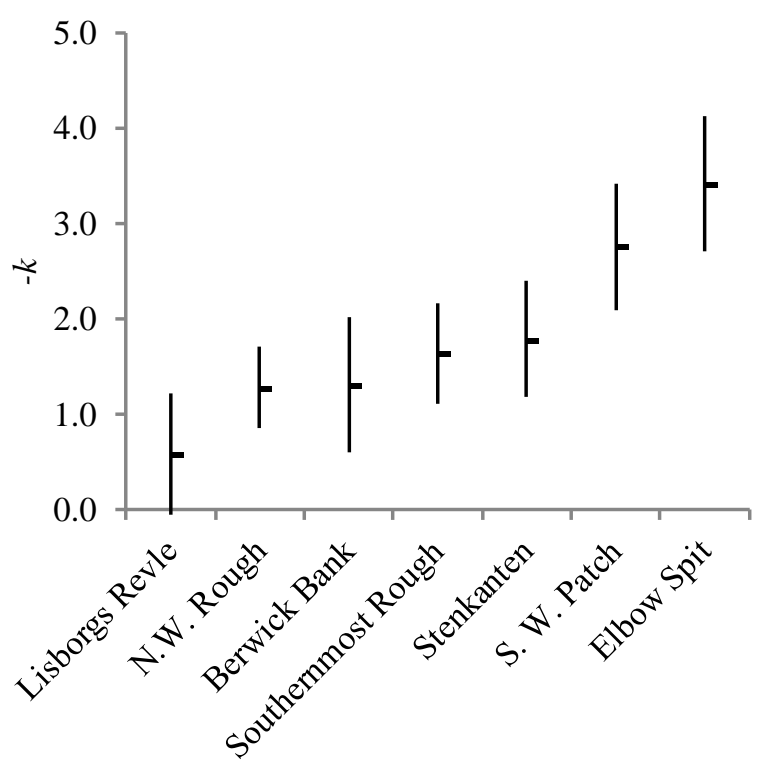

630

631 Fig. 6. Average $-k=\ln \hat{C}_{1, y-1}-\ln \hat{C}_{2, y}$, an indicator of total mortality combined with relative 632 catchability of ages 2 and 1.

633 


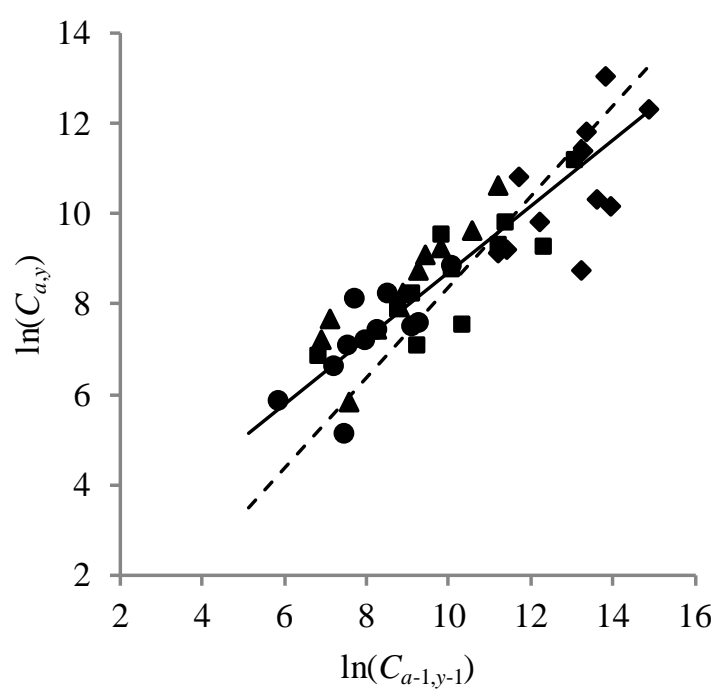

635

636 Fig. 7. Index of abundance of sandeel of age $a$ in year $y$ as a function of the abundance of 1-year

637 younger fish the previous year. Diamonds: 1-year olds, squares: 2-year olds, triangles: 3 year olds 638 and circles: 4 year olds. Hatched line indicates a slope of 1, solid line is a regression line common 639 for all ages assuming gamma error distribution of $C_{a, y}$. Data from sandeel at Shetland by Cook 640 (2004). 

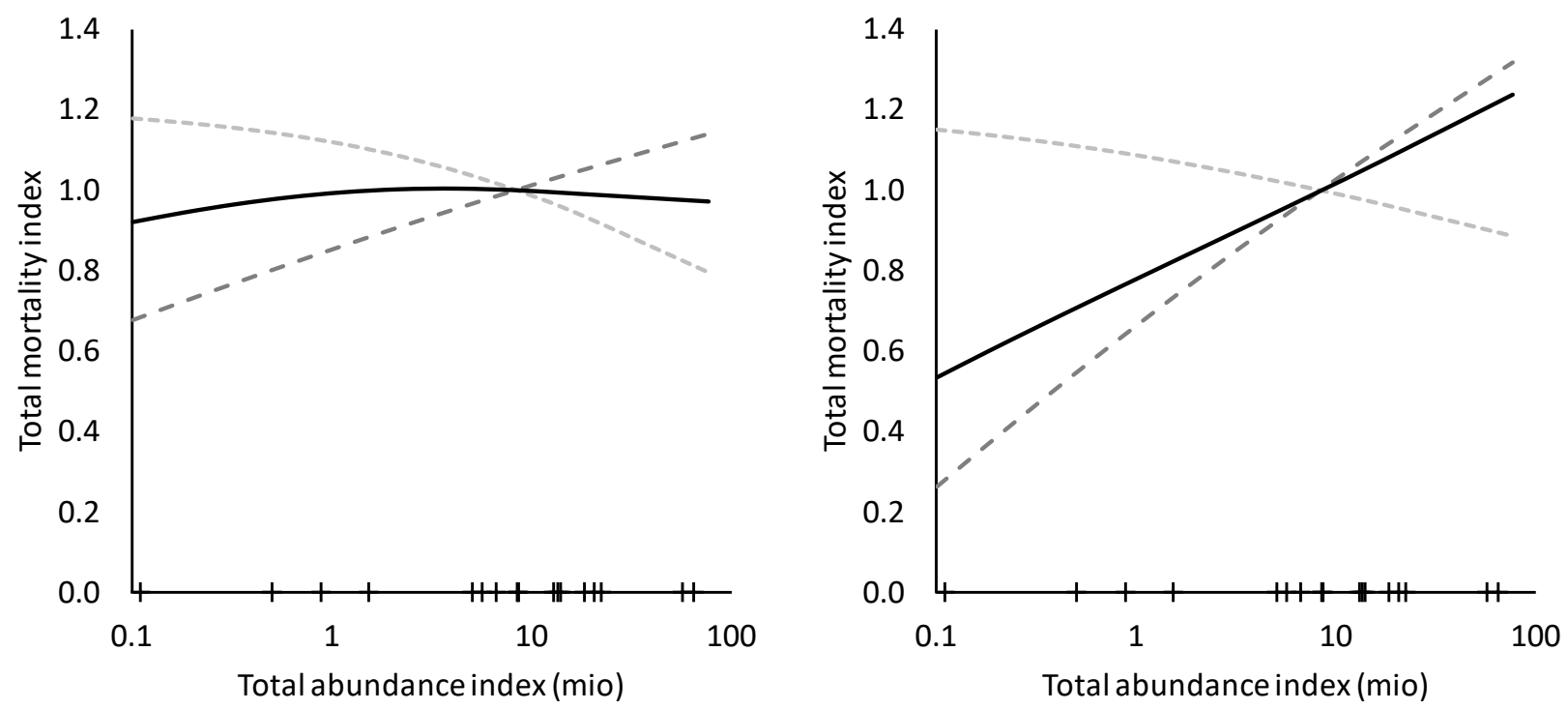

643 Fig. 8. The combined effect of local density dependent recruitment and mortality. Index of total

644 mortality as a function of an index of total abundance of sandeel in area 1. Left panel: estimated

645 for all fishing grounds. Right panel: estimated for all fishing grounds except S. W. Patch. Light grey

646 dotted line: density dependent recruitment and density independent local mortality. Dark grey

647 broken line: density independent recruitment and density dependent local mortality. Black solid

648 line: density dependent recruitment and density dependent local mortality. Vertical lines at the

649 axis indicate annually observed abundance indices. Lines are scaled to be 1 at the median

650 abundance index. 

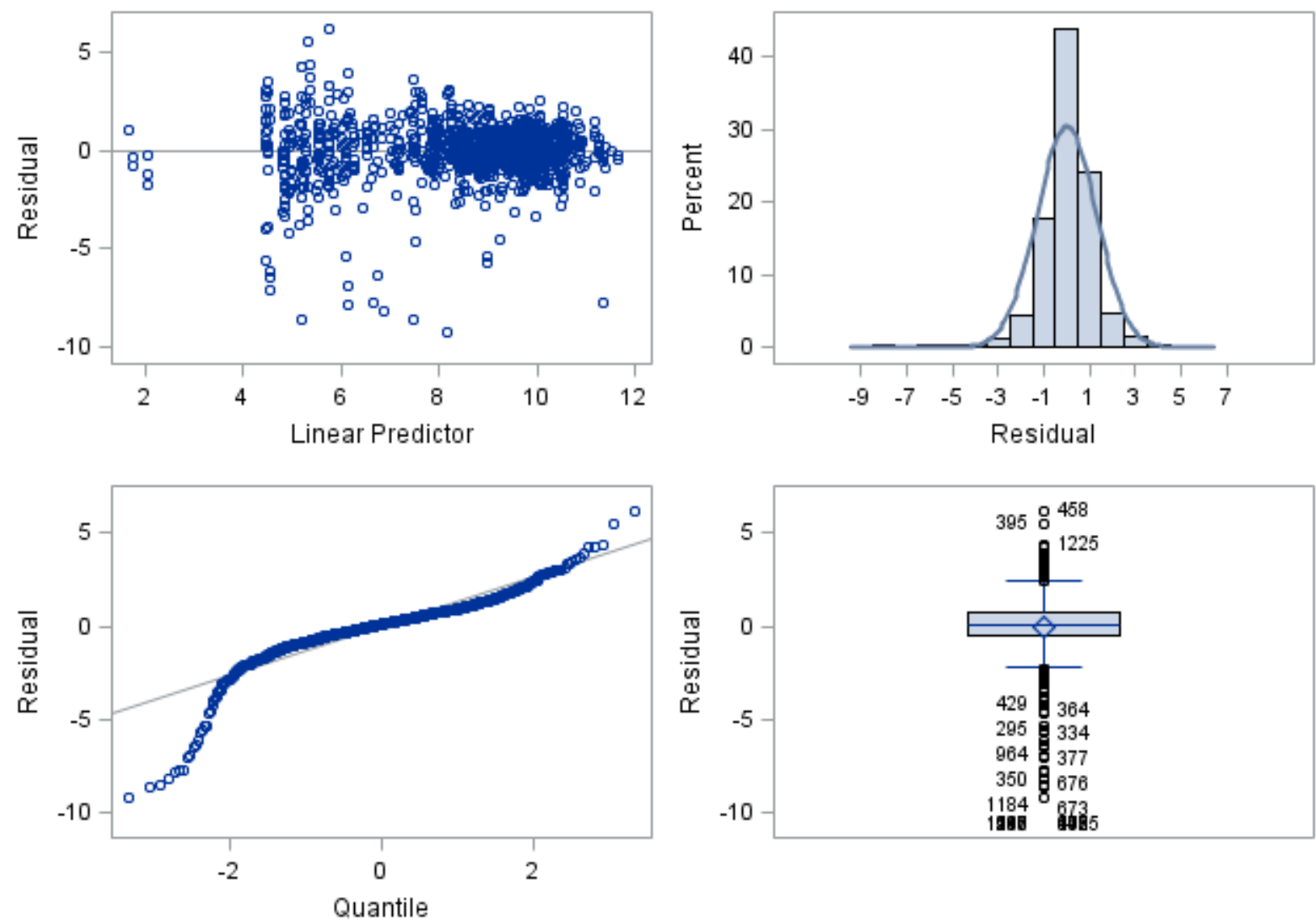

653

654 Fig. S1. Residual plots for reduced model $1\left(\ln \hat{C}_{1, g, y}=k_{g}+\gamma_{g} \ln \bar{C}_{1, N W R o u g h, y}+\omega_{g, y}+\varphi_{v}\right)$ for 655 grounds in assessment area 1. 

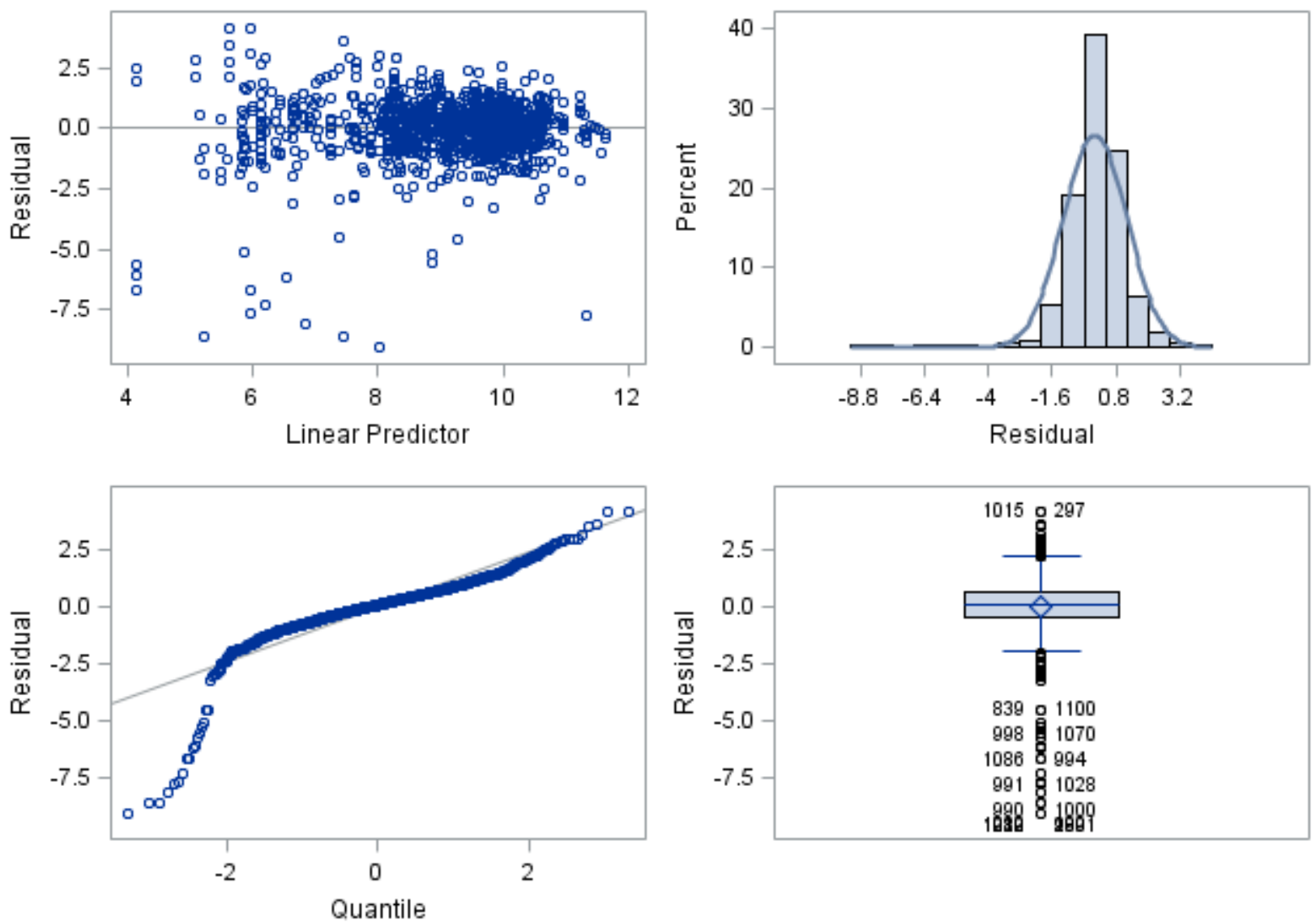

656

657 Fig. S2. Residual plots for reduced model $2\left(\ln \hat{C}_{1, g, y}=k_{g}+\eta_{g} \ln R_{1, y}+\omega_{g, y}+\varphi_{v}\right)$ for grounds in 658 assessment area 1. 

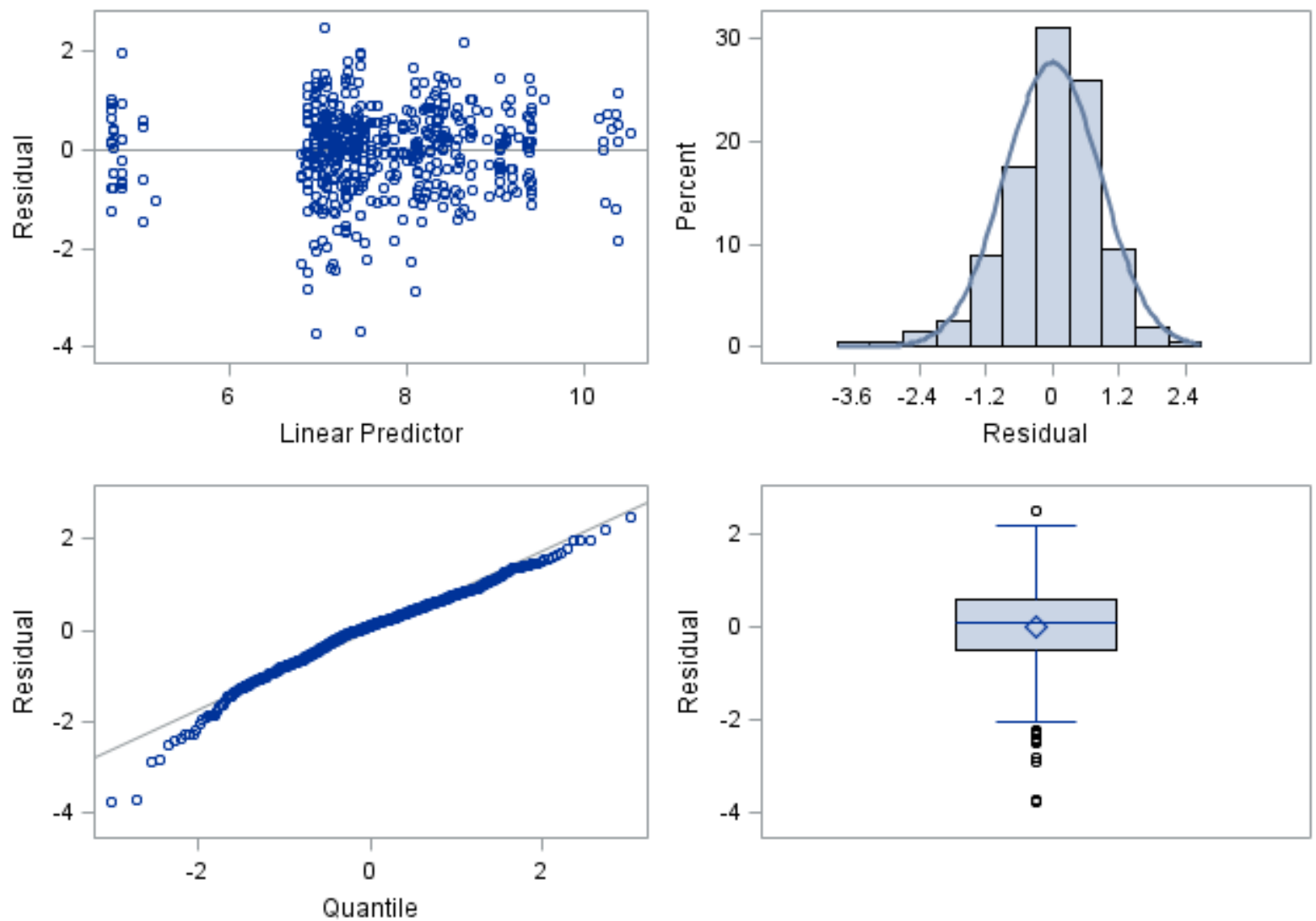

660

661 Fig. S3. Residual plots for reduced model $4\left(\ln \hat{C}_{2, y+1}=k_{0}+k_{1} y+(1-\beta) \ln \bar{C}_{1, y}+\omega_{g, y}+\varphi_{v}\right)$ for 662 N. W. Rough and Southernmost Rough.

663

664 